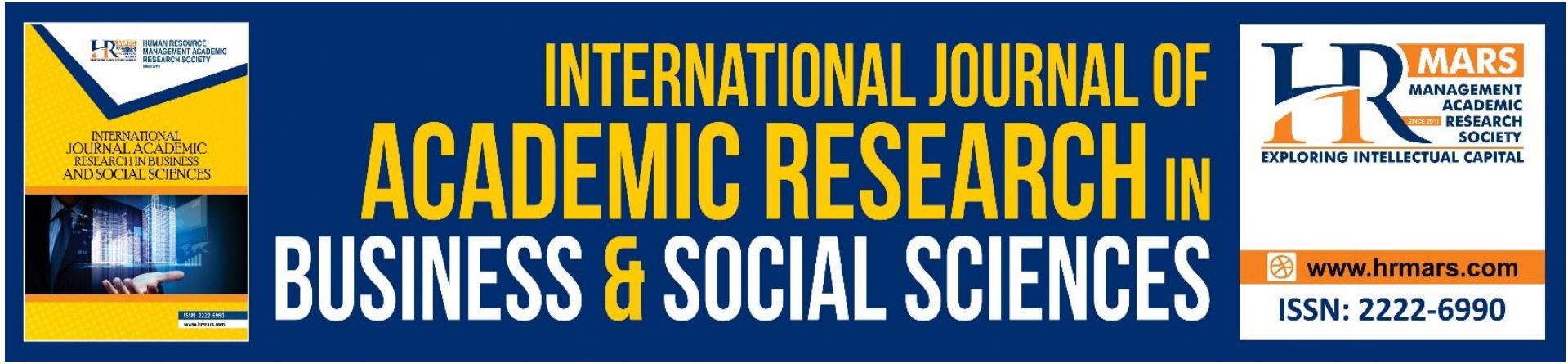

\title{
The Relationship between Lg120 Students' Personality Traits and Their Character Preferences in 'The Importance of Being Earnest' by Oscar Wilde
}

Siti Zarikh Sofiah Abu Bakar, Haniza Sarijari, Dia Widyawati Amat, Zuraidah Sumery, Diana Othman, Fairuz Husna Mohd Yusof

To Link this Article: http://dx.doi.org/10.6007/IJARBSS/v11-i7/10329

DOI:10.6007/IJARBSS/v11-i7/10329

Received: 21 May 2021, Revised: 23 June 2021, Accepted: 11 July 2021

Published Online: 28 July 2021

In-Text Citation: (Bakar et al., 2021)

To Cite this Article: Bakar, S. Z. S. A., Sarijari, H., Amat, D. W., Sumery, Z., \& Othman, D. (2021). The Relationship between Lg120 Students' Personality Traits and Their Character Preferences in 'The Importance of Being Earnest' by Oscar Wilde. International Journal of Academic Research in Business and Social Sciences, 11(7), 547-560.

Copyright: (c) 2021 The Author(s)

Published by Human Resource Management Academic Research Society (www.hrmars.com)

This article is published under the Creative Commons Attribution (CC BY 4.0) license. Anyone may reproduce, distribute, translate and create derivative works of this article (for both commercial and non-commercial purposes), subject to full attribution to the original publication and authors. The full terms of this license may be seen

at: http://creativecommons.org/licences/by/4.0/legalcode

Vol. 11, No. 7, 2021, Pg. 547 - 560

Full Terms \& Conditions of access and use can be found at http://hrmars.com/index.php/pages/detail/publication-ethics 


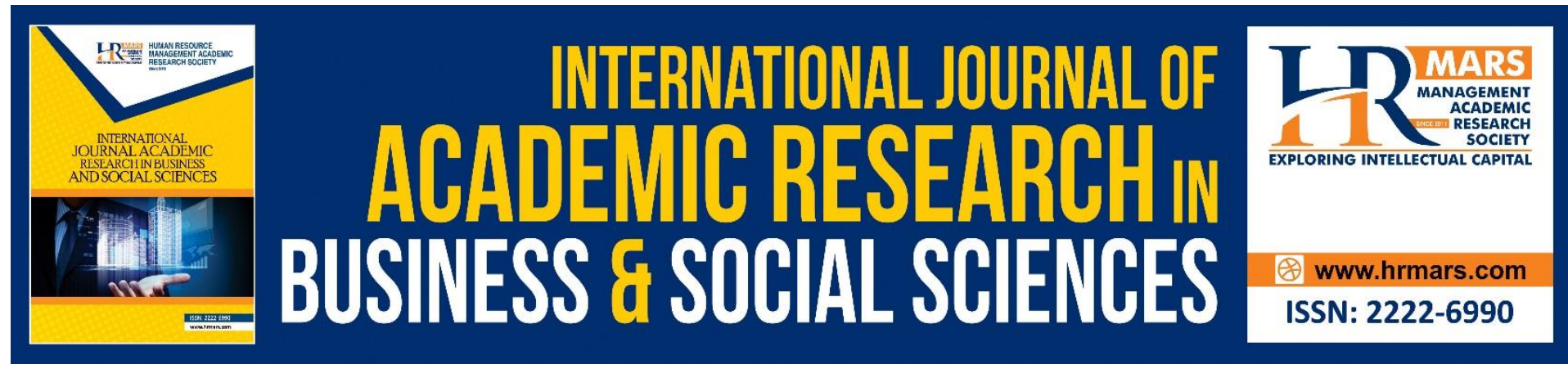

\title{
The Relationship between Lg120 Students' Personality Traits and Their Character Preferences in 'The Importance of Being Earnest' by Oscar Wilde
}

\author{
Siti Zarikh Sofiah Abu Bakar, Haniza Sarijari, Dia Widyawati \\ Amat, Zuraidah Sumery, Diana Othman \\ Academy of Language Studies, Universiti Teknologi MARA Cawangan Johor, 85000 Johor, \\ Malaysia \\ Email: sitiz148@uitm.edu.my, haniz652@uitm.edu.my, diawi188@uitm.edu.my,
} zurai012@uitm.edu.my, diana481@uitm.edu.my

\section{Fairuz Husna Mohd Yusof}

Academy of Language Studies, Universiti Teknologi MARA Shah Alam, 40450 Shah Alam, Selangor, Malaysia

Email: fairu305@uitm.edu.my

\begin{abstract}
Literary appreciations are people's responses about works of literature, whether they are formal or informal reviews, laymen or scholars (Pope, 1998 as cited in Ghabanchi \& Doost, 2012). Thus, it is a subjective matter that requires no definite answer scheme in literature class. Students are free to interpret and explain the subject based on their opinion and understanding inasmuch as it revolves around that assigned literary work. The similar idea is practised by LG120 (Diploma in English for Professional Communication) students from UiTM (Universiti Teknologi MARA) Cawangan Johor, Segamat campus, in their Introduction to Literature (ALS103) class. As expected, various interpretations and answers produced, which directly or indirectly challenge the teachers in responding to them. Since students possess different personalities, this study should help the teachers to prepare themselves in formulating their responses too. Therefore, this study is keen to investigate the potential relationship between personal traits namely introversion, extroversion and ambiversion and the students' literary appreciation on a play entitled 'The Importance of Being Earnest' by Oscar Wilde which focuses on the character preferences. The study involved 17 LG120 Semester 1 students from UiTM Johor, Segamat campus. A mixed-method sequential explanatory study involving quantitative; questionnaires on the personality traits and qualitative; online interview on character preferences approach was utilised. The quantitative data obtained from the questionnaires on their personality traits were analysed using SPSS for frequencies which then be paired together with the data obtained from the online interview, and were analysed using Pearson's $r$ to measure the relationship between the
\end{abstract}


students' personality traits and their character preferences. As previous literatures have listed significant relationship between roughly comparable variables, this study expects to venture the parallel findings.

Keywords: Literary Appreciation, Personality Traits, Significant Relationship, Character Preferences, The Importance of Being Earnest

\section{Introduction}

The level of satisfaction in enjoying a piece of literature differs from one to another. As John Medina (n.d.), a developmental molecular biologist and research consultant highlighted in brainrules.net, not even identical twins can have the exact same experiences, and their brains are not wired the same way. This explains the possibility of having various appreciations of literary works gathered from different individuals. In the case of facilitating a literature class, these variations of individuals and their personalities should be made known to the teachers in preparing and conducting a fruitful and exciting lesson, as well as responding to their students' views and behaviours in class. Cook (1991) has listed three benefits of having a personality study namely gaining scientific understanding, accessing people, and changing people. In brief, the second benefit should be best highlighted to express the objectives of the study.

Teachers are the most anxious individuals when it comes to providing an effective and enjoyable learning experience to their students. Their efforts include providing attractive notes, additional teaching and learning tools in class, experimenting different approaches to grab the students' attention, and other remarkable attempts. However, all the efforts will be a waste if they are not aware of the actual contributing element that influences the students' preferences. Similarly, the awareness should also exist in reacting to students' responses in a literature class especially when their exercise is focusing on literary appreciation. As we have been schooled, there is no definite answer for a literary appreciation as their opinion depends on their understanding, prior knowledge, and experience. Therefore, it is crucial for the teachers to explore the students' personality traits (introversion, extroversion, ambiversion) before responding or commenting on their literary appreciations. As supported by Erton (2010), interest on how personality correlates to the teaching and learning process has started to grow since 1990s, which proves the significance of studying the issue.

\section{Research Objectives}

The research objectives are:

1) To investigate whether there is a significant relationship between students' personality traits (introversion, extroversion, ambiversion) and their character preferences in 'The Importance of Being Earnest' by Oscar Wilde.

2) To identify the most popular character chosen by the students for each personality traits (introversion, extroversion, ambiversion) in 'The Importance of Being Earnest' by Oscar Wilde.

\section{Research Questions}

The research questions are:

1) Is there any significant relationship between students' personality traits (introversion, extroversion, ambiversion) and their character preferences in 'The Importance of Being Earnest' by Oscar Wilde? 
2) Who is the most popular character chosen by the students for each personality traits (introversion, extroversion, ambiversion) in 'The Importance of Being Earnest' by Oscar Wilde?

\section{Research Hypotheses}

The research hypotheses are:

$\mathrm{H}_{0}$ : There is no significant relationship between students' personality traits (introversion, extroversion, ambiversion) and their character preferences in 'The Importance of Being Earnest' by Oscar Wilde.

\section{Literature Review \\ Literary Appreciation}

Literary appreciation can be defined as the act of responding to a literary work by commenting or expressing opinions (Pope, 1998 as cited in Ghabanchi \& Doost, 2012). It can be done by anyone, be it students of literature, students of engineering, and even village folks from the countryside which their daily routine involves farming and rubber-tapping.

\section{Personality Traits}

Hockenbury and Hockenbury (2010) defined personality as intellectual, affective, and behavioural variations that differentiate one individual to another. Meanwhile, Atli (2017) viewed personality as a factor in determining the way a person would behave under numerous situations.

According to Sadeghi, Kasim, Tan and Abdullah (2012), it is important to note that the terms 'types' and 'traits' have been used interchangeably in several studies. Nevertheless, these two terms carry simple different concepts from psychological and theoretical points of view; personality type theory refers to the psychological classification of different types of people and it is differentiated from personality traits, which refers to different levels or degrees. For instance, personality types refer to the introverts, extroverts and ambiverts, while personality traits refer to introversion, extroversion and ambiversion. However, De Raad (1996) stated that there are no clear differences between traits and types. Therefore, these two types are used interchangeably in this study.

According to the study by Wakamoto (2000) as cited in Noprianto (2017), extroversion and introversion are widely acknowledged concepts which are referring to personality traits. Even though these terms are widely acknowledged, no individual can be clearly classified into any of it as every individual basically possess both traits, but with different ratio.

The following section covers the definition of each trait as explained by Petric (n.d.) in his study on introvert, extrovert and ambivert;

Introversion. Based on the study, introversion is the state of being predominantly interested in one's own mental self. Individuals who belong to this group usually viewed as more reserved or reflective. There are also advantages of being an introvert which he or she can reflect, able to be alone and capable of working independently. However, these individuals also possess several weak points which are having difficulties when working in a team, socialising, as well as doing public speaking. For this study, the introverts in the play were 
operationally defined based on their timid characteristics, low frequency of interaction with other characters, and short dialogues uttered by them.

Extroversion. This is the state of primarily obtaining gratification from outside oneself. The extroverts usually celebrate human interactions and highly enthusiast in meeting and talking to people while appear energised when socialising. Among the advantages of being extroverts are having the abilities to socialise, work in a team and enjoy public speaking. Other than the advantages, the disadvantages of being an extrovert are it is hard for them to work alone or independently as they depend so much on others to understand or comprehend an instruction. Therefore, it is hard for them to survive when experiencing social isolation. As from the play, the extroverts were operationally classified based on their outgoing characteristics, high frequency of interaction with other characters and varieties of dialogues created for them.

Ambiversion. In 1923, Conklin proposed that ambiversion refers to the normal people in between the introversion and extroversion categories. Davidson (2017) further explained his statement that the ambivert was also regarded as personality non grata. In other words, this is the trait that is not welcomed to any of the two earlier traits. Furthermore, the ambiverts usually change their behaviours according to the situation they are in. For instance, an individual might be an extrovert by being so talkative and friendly with the presence of family members or close friends but change to an introvert the moment they met strangers. In sum, ambiversion is the most adaptive and stable combination of introversion and extroversion. The operational definition of ambiversion for the characters in the play was categorised based on the hybrid personalities between timid and outgoing, the silent and active moment experienced by the characters, and the varieties and balanced amount of dialogue assigned to the characters.

\section{The Writer: Oscar Wilde}

Oscar Wilde is an Irish author who was born on October 16, 1854 in Dublin, Ireland by the full name Oscar Fingal O'Flahertie Wills Wilde. He died on 30 th November 1900 in Paris, France. His parents were a surgeon and a revolutionary poet. Having a wonderful parents and background led him to be a successful writer with several famous literary works. His greatest works were about society comedies where he employed his paradoxical, epigrammatic wit to create humour which was new to the $19^{\text {th }}$-century English theatre of the era. Among his famous works are Lady Windermere's Fan, A Woman of No Importance, The Importance of Being Earnest, and other remarkable works (Beckson, 2020)

\section{The Play: The Importance of Being Earnest}

The full title of the play is The Importance of Being Earnest: A Trivial Comedy for Serious People. Wilde divided this play into three acts which was performed in 1895 and published in 1899. This play is considered as Wilde's greatest dramatic achievement where it portrays a satire of Victorian social hypocrisy.

The play presented a fashionable young man named Jack Worthing who lives in the country with his ward, Cecily Cardew. He invented a dashing brother named Ernest who is supposed to be an excuse for him to travel to London periodically. Jack falls in love with his friend's cousin named Gwendolen Fairfax. Gwendolen who thinks Jack's name is Ernest, returns his 
love but the relationship is objected by her mother, Lady Bracknell since Jack is an orphan who was found in a handbag at Victoria Station. Meanwhile, Gwendolen's cousin, Algernon Moncrieff, who is also Jack's friend has also been impersonating Ernest to woo Cecily who has admired the imaginary Ernest. The play ends with the revelation of Jack's identity which his real name is Ernest, born as the brother of Algernon and the nephew of Lady Bracknell. In summary, both couples are happily united as the play resolved (The Editors of Encyclopaedia Britannica, 2015).

\section{Main Characters}

Sparknotes Editors (n.d.) and Van Kirk (n.d.). (1) Jack Worthing represents an upper-class Victorian who has earned respects because of his adopter father's wealth. He has no problems in socialising and meeting the crowd as proved in the play where he mingles well with his adopted family, and Algernon's family especially Gwendolen who he has fallen in love to. Other than that, he is also able to tease the public by showing his wit and enormous sense of humour. However, he also leads a life full of deception for pleasure when he is in the city as he has a created brother named Ernest. In brief, his deception is mainly caused by his enjoyment of going to the city for socialising purposes. The details suggested that he is an extrovert character in the play.

(2) Algernon Moncrieff is a member of the wealthy class, residing in London. He is a narcissist who likes to boast about his clever thinking, and regarded as an Oxonian by his aunt, Lady Bracknell. He is always frivolous and irreverent to the idea of romance and marriage. He mingles well his family, but always refuses to join social gathering especially the one planned by his aunt. In other words, he celebrates gathering, but only the one which the guest list is upon his approval. As a result, he created a fictional friend called Bunbury to avoid going to any social activities or gatherings which are not in his list. In sum, Algernon's traits suggested that he is an ambivert character in the play.

(3) Gwendolen Fairfax is the beautiful daughter of Lady Bracknell, who is in love with Jack Worthing, whom she knows as Ernest. She is very sophisticated, intellectual but a bit narrowed-minded as she believes only the man with the name Ernest is the best man to get married with. The play does not really reveal her social life and friends other than when meeting with her cousin, Algernon, and the man she loves, Jack. Furthermore, the play notes that Gwendolen hates the crowd, where it can be summarised that she represents an introvert character in the play.

(4) Cecily Cardew is the granddaughter of Jack's adopter father who is 18 years old and lives in the country. She is also obsessed with the man named Ernest as she has her own diary writing all her feelings and hopes towards Ernest whom she has never met. She is an outgoing and friendly person who greets her guest warmly even though she has never met them. She also hopes to have Ernest, the man she has never met to be the guest as her house. Cecily celebrates social gatherings up to the extent that she admits being 20 years old rather than her younger age just to make sure she can attend those. This in fact shown that she is an extrovert character in the play.

\section{Supporting Characters}

Sparknotes.com and Cliffnotes.com (n.d.); (1) Lady Bracknell is the snobbish, cunning, and authoritarian mother of Gwendolen and aunt of Algernon. She is also very firm in choosing Gwendolen's future husband as to maintain their social status. She always throws a dinner 
party at her house to socialise with others and enjoys talking to her guest. The details listed clearly drafted that Lady Bracknell is an extrovert character in the play.

(2) Miss Prism is Cecily's governess. She adores Jack's persona yet criticises Ernest who she thinks as the unfortunate brother of Jack. She enjoys reading and writing as a way of expressing her feelings as she seems so shy to openly talk about them. Most of her scenes are at the house without any revelation of other social activities in the play. Thus, as she secretly entertains feelings for Dr. Chasuble in the play, she can be regarded as an introvert character. (3) Reverend Canon Chasuble, D.D is the rector on Jake's estate. He is a kind and friendly person who is willing to entertain people's sudden request without any hesitation. Even though it is the nature of his job, that shows how free and easy-going he is. Other than that, by being a priest, that does not stop him from entertaining romantic feelings for Miss Prism. From the traits shown, there is no doubt that he is an extrovert character in the play.

(4) Lane is the manservant at Algernon's house. The play does not show other activities involved by Lane other than his scene with Algernon. In fact, he is the only person who keeps the secret of Algernon's practice of Bunburying. Therefore, Lane can be categorised as an introvert character in the play.

(5) Merriman is the butler at Jack's house in the country. Likewise, there are not many details revealed about him in the play. Therefore, with that little information, he can also be listed under the introvert characters in the play.

\section{Research Gap}

Studies on the relationship between personality traits and preferences are abundant and sought after. Previous researchers were interested in exploring how personality traits affect systems-thinking skills preferences (Nagahi et al., 2020), leadership preferences (Breevaart \& Vries, 2019), user experience for music streaming services (Ferwerda et al., 2019), Social Networking Sites (SNS) preferences (Hou et al., 2018), music taxonomy preferences (Schafer \& Mehlhorn, 2017; Ferwerda et al., 2015), grocery item preferences (Yangui, Costa-Font \& Gil, 2016), brand preferences (Banerjee, 2016), and artistic preferences (Furnham \& Walker, 2001), to name a few. However, there is a scarcity in the research of how personality traits affect readers' preferences of literary characters. One previous study that is deemed the closest to the current paper was conducted by Kroneisen and Heck (2019) that explored the influence of personality traits in moral decision making based on the action taken by a literary character. In the economics, personality traits are also said to be related to preference heterogeneity (Peschel et al., 2019); therefore, it is the intention of the current research to investigate if personality traits determine literary character preferences as well.

\section{Methodology}

\section{Research Design}

A mixed-method sequential explanatory study involving quantitative; questionnaires on their personality test, and qualitative; online interview approach was utilised.

\section{Research Method}

Sample The sample ( $n$ ) chosen for the study were 17 LG120 (Diploma in English for Professional Communication) Semester 1 students from UiTM (Universiti Teknologi MARA) Cawangan Johor, Segamat campus.

Sample Selection A purposive sampling method was used in identifying the respondents from one Literature class. These are the students who are supposed to complete Introduction to 
Literature course (ALS103) during Semester 1. In this class, they were exposed to various literary works, as well as literary appreciation practices and assignments. The students' personality traits were assessed using the available online test; developed by Adam (2018) https://ideas.ted.com/quiz-are-you-an-extrovert-introvert-or-ambivert/.

\section{Research Procedures}

This study was carried out for 4 months. The quantitative data obtained from the questionnaires on their personality traits will be analysed using SPSS for frequencies which then be paired together with the data obtained from the online interview on character preferences, and will be analysed using Pearson's $r$ to measure the relationship between the students' personality traits and their character preferences. Other than that, a thematic analysis will also be executed to detail out the reasons behind the students' chosen characters.

\section{Findings}

This section highlights the results of the study based on the research questions.

RQ1: Is there any significant relationship between students' personality traits (introversion, extroversion, ambiversion) and their character preferences in 'The Importance of Being Earnest' by Oscar Wilde?

Correlational analyses were conducted to examine the significant relationship ( $p$-value $=0.05$ ) between student's personality traits (introversion, extroversion, ambiversion) $(M=2.41, S D$ $=.870)$ and their character preferences $(M=3.0, S D=1.173)$ in 'The Importance of Being Earnest'. The Pearson's $r$ data analysis revealed a weak positive correlation, $r(15)=.245, p=$ .343 , but there is not enough evidence proving that their relationship is statistically significant. The results are displayed in the following tables.

Table 1

Correlations

\begin{tabular}{llll}
\hline & & $\begin{array}{l}\text { introvert } \\
\text { extrovert } \\
\text { ambivert }\end{array}$ & all characters \\
\hline introvert & Pearson Correlation & 1 & .245 \\
extrovert & Sig. (2-tailed) & & .343 \\
ambivert & $\mathrm{N}$ & 17 & 17 \\
all characters & Pearson Correlation & .245 & 1 \\
& Sig. (2-tailed) & .343 & \\
& $\mathrm{~N}$ & 17 & 17 \\
\hline
\end{tabular}

Since $p$-value recorded is .343, this study failed to reject the null hypothesis proposed earlier; $H_{0}$ : There is no significant relationship between students' personality traits (introversion, extroversion, ambiversion) and their character preferences in 'The Importance of Being Earnest' by Oscar Wilde. Meanwhile, $H_{1}$ : There is a significant relationship between students' personality traits (introversion, extroversion, ambiversion) and their character preferences in 'The Importance of Being Earnest' by Oscar Wilde is rejected. 
RQ2: Who is the most popular character chosen by the students for each personality traits (introversion, extroversion, ambiversion) in 'The Importance of Being Earnest' by Oscar Wilde?

Descriptive statistics for frequencies were computed to identify the most preferred character chosen by the students according to their personality traits (introversion, extroversion, ambiversion). The four introvert students have chosen Jack Worthing (25\%), Algernon Moncrief (25\%), Cecily Cardew (25\%) and Gwendolen Fairfax (25\%) as their favourite character. Meanwhile, two extrovert students preferred Jack Worthing (50\%) and Lady Bracknell (50\%) as their favourite characters. The last group of students which are the ambiverts have chosen Cecily Cardew (45.5\%), Gwendolen Fairfax (36.4\%) and Jack Worthing $(18.2 \%)$ as their favourite character. The details are presented in the table below.

Table 2

Frequencies for Introversion

\begin{tabular}{llllll}
\hline & & & & Cumulative \\
& & Frequency & Percent & Valid Percent & $\begin{array}{l}\text { Percent } \\
\text { Valid }\end{array}$ \\
& Jack Worthing & 1 & 9.1 & 25.0 & 25.0 \\
& Algernon Moncrief & 1 & 9.1 & 25.0 & 50.0 \\
& Cecily Cardew & 1 & 9.1 & 25.0 & 75.0 \\
& Gwendolen Fairfax & 1 & 9.1 & 25.0 & 100.0 \\
& Total & 4 & 36.4 & 100.0 & \\
Missing & System & 7 & 63.6 & & \\
Total & & 11 & 100.0 & &
\end{tabular}

Table 3 Frequencies for Extroversion

\begin{tabular}{llllll}
\hline & & & & Cumulative \\
& & Frequency & Percent & Valid Percent & \begin{tabular}{l} 
Percent \\
\hline Valid
\end{tabular} \\
& Jack Worthing & 1 & 9.1 & 50.0 & 50.0 \\
& Lady Bracknell & 1 & 9.1 & 50.0 & 100.0 \\
& Total & 2 & 18.2 & 100.0 & \\
Missing & System & 9 & 81.8 & & \\
Total & 11 & 100.0 & &
\end{tabular}

Table 4 Frequencies for Ambiversion

\begin{tabular}{llllll}
\hline & & & & Cumulative \\
& & Frequency & Percent & Valid Percent & Percent \\
\hline Valid & Jack Worthing & 2 & 18.2 & 18.2 & 18.2 \\
& Cecily Cardew & 5 & 45.5 & 45.5 & 63.6 \\
& Gwendolen Fairfax & 4 & 36.4 & 36.4 & 100.0 \\
& Total & 11 & 100.0 & 100.0 &
\end{tabular}

To further address RQ2, the recorded and transcribed online interview data were analysed using thematic analysis approach. Based on the analysis, three main themes of their reasoning for choosing a certain character were identified as displayed in the following tree diagram. 


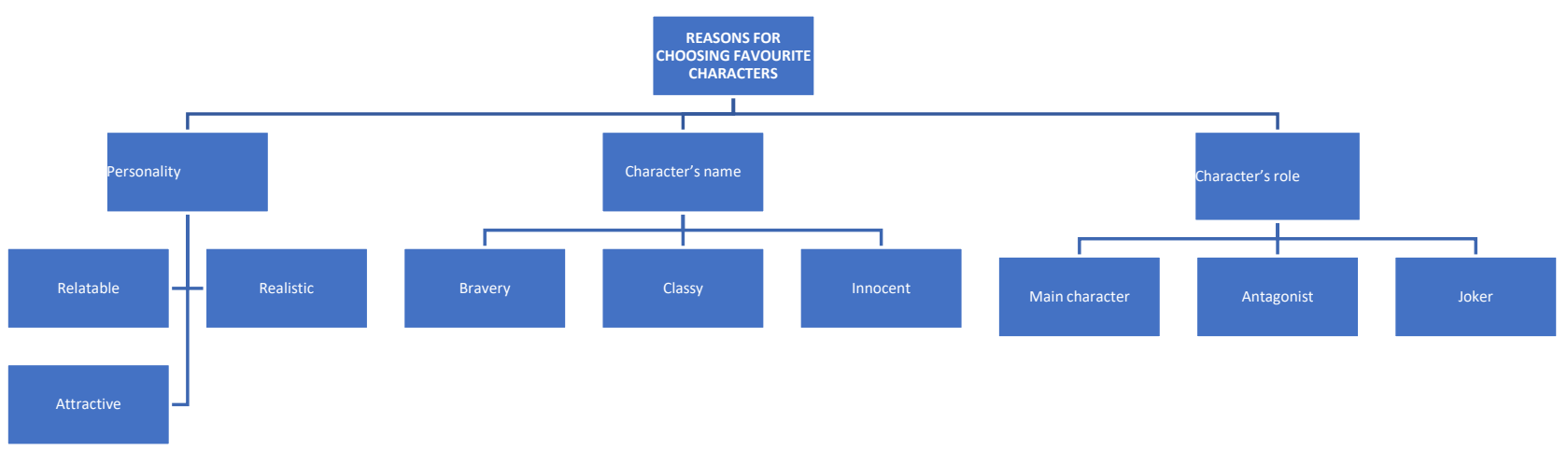

Figure 1. Tree diagram (Reasons for choosing their favourite character)

Meanwhile, for further minutiae, the following table presents the lists of some interview excerpts for the respective themes identified.

\begin{tabular}{|c|c|c|}
\hline Category & Term in Category & $\begin{array}{l}\text { Interview } \\
\text { excerpt }\end{array}$ \\
\hline \multirow[t]{3}{*}{ Personality } & Relatable & $\begin{array}{l}\text { Jack Worthing's } \\
\text { personality is } \\
\text { relatable to mine. }\end{array}$ \\
\hline & Realistic & $\begin{array}{l}\text { Cecily Cardew's } \\
\text { character is very } \\
\text { realistic as we are } \\
\text { in real life. }\end{array}$ \\
\hline & Attractive & $\begin{array}{l}\text { Gwendolen } \\
\text { Fairfax is so } \\
\text { attractive that } \\
\text { helps me to finish } \\
\text { reading the play. }\end{array}$ \\
\hline \multirow[t]{3}{*}{ Character's name } & Innocent & $\begin{array}{l}\text { Cecily sound so } \\
\text { naïve } \\
\text { innocent. }\end{array}$ \\
\hline & Classy & $\begin{array}{l}\text { Gwendolen } \\
\text { Fairfax portrays a } \\
\text { classy and } \\
\text { fashionable } \\
\text { woman. }\end{array}$ \\
\hline & Bravery & $\begin{array}{l}\text { Jack Worthing } \\
\text { sound so kind, } \\
\text { responsible and } \\
\text { brave. }\end{array}$ \\
\hline Character's role & Main character & $\begin{array}{l}\text { Jack Worthing is } \\
\text { the main and } \\
\text { important } \\
\text { character in the } \\
\text { play. }\end{array}$ \\
\hline
\end{tabular}




\begin{tabular}{|l|l|l|}
\hline & Joker & $\begin{array}{l}\text { Algy is } \\
\text { mischievous and } \\
\text { canny. }\end{array}$ \\
\cline { 2 - 4 } & Antagonist & $\begin{array}{l}\text { Lady Bracknell is } \\
\text { so attractive even } \\
\text { though she is an } \\
\text { antagonist. }\end{array}$ \\
\hline
\end{tabular}

Figure 2. Thematic Analysis (Reasons for choosing their favourite character)

\section{Discussion}

RQ1 has been answered with a weak positive correlation result. This means, even though the students' personality traits show possible influence on their character preferences, the relationship is not very strong. In other words, apart from the different characters chosen by different personality traits documented, the circumstance of similar characters to be chosen still exists.

RQ2 highlights favourite characters of the play chosen by the students based on their personality traits. Cecily Cardew has been chosen as the most preferred character of the play by the ambivert students, while the introvert and extrovert students have no outstanding number recorded for any of the characters. In supporting the frequencies, answers from the online interview will be detailed out. Based on the thematic analysis conducted, the three themes identified are personality, character's name, and character's role. For personality, it was found that Cecily Cardew is a realistic character while Gwendolyn Fairfax is the attractive one. The insignificant preferences on a realistic and the attractive characters by the introverted respondents contradict Dunn and Guadagno (2011) who found that introverted individuals prefer attraction in characters. The interview results also show that the students' basis in choosing their favourite characters are not merely focusing on the character's personality traits, but also measured by their names and roles presented in the play. In brief, the students are not caged with only comparing the characters' personality traits and their personality traits, but they are also opened to consider other elements in valuing the characters in the play. Hence, the weak positive correlation result.

The findings that may differ from past studies serve as an opportunity for more exploration on personality traits and literary character preferences. As stated by Aras (2015), the interdisciplinary structure of literature does not go unnoticed since a strong correlation between psychology and literature is evidently there.

\section{Limitations}

The sample selected for this study was specifically students who were still in the stage of completing the Literature course which their knowledge and experience might not be as wide as Literature students who have graduated from the same course. Therefore, the results obtained may not be applicable to other students from different courses or different semesters. Furthermore, the students took only a simple personality test in determining their personality traits. Consequently, a more detailed personality test could suggest different results. 


\section{Recommendations}

For future research, it is recommended to use this procedure with different group of students and a more detailed personality test in categorising their personality traits.

\section{Conclusion}

In conclusion, since there is only a weak positive relationship between personal traits namely introversion, extroversion and ambiversion and the students' literary appreciation on the play 'The Importance of Being Earnest' by Oscar Wilde, the teachers can still respond to students' works generally. However, it is still essential for teachers to prepare themselves in responding and treating students' literary appreciation fairly to avoid any demotivating and destructive comments delivered.

This study should be a good contribution to the education field especially amidst the challenging pandemic situation where the traditional classroom has been shifted to Open and Distance learning (ODL) medium where educators find it hard to read the students' personalities. The absence of knowledge about the students' personalities can result in the misunderstanding that eventually leads to mistreatment in a class setting. As this study uses the personality traits of the students as the main variable, educators can strategize a similar approach in class as part of their ice-breaking activities for future reference.

Moreover, since this study analyses the students' personality traits and their character preferences from a literary work, the findings are coveted to provide the educators especially those in a literature class with some suggestions and explanations for the variations of responses they have received in class. Apart from that, the findings can also support and guide the educators in expressing their responses without discouraging the students instead encouraging them to participate in class.

\section{References}

Adam. (2018) We humans. Retrieved from https://ideas.ted.com/quiz-are-you-an-extrovertintrovert-or-ambivert/

Aras, G. (2015). Personality and individual differences: Literature in psychology- Psychology in literature. Procedia-Social and Behavioral Sciences, 185, 250-257.

Atli, A. (2017). Five-Factor Personality Traits as Predictor of Career Maturity. Eurasian journal of educational research, 68, 151-165.

Banerjee, S. (2016). Influence of consumer personality, brand personality, and corporate personality on brand preference: An empirical investigation of interaction effect. Asia Pacific Journal of Marketing and Logistics, 28 (2) https://doi.org/10.1108/APJML-052015-0073

Beckson, K. (2021). Oscar Wilde. Encyclopedia Britannica. https://www.britannica.com/biography/Oscar-Wilde

Breevaart, K., \& Vries, R. E. (2019). Followers' HEXACO personality traits and preference for charismatic, relationship-oriented, and task-oriented leadership. Journal of Business and Psychology, https://doi.org/10.1007/s10869-019-09671-6

Casey, B., \& Tran, A. (2014). The introvert, extrovert, and ambivert: mood implications within text messages.

Cook, V. (1991). Second language learning and language teaching. London: Edward Arnold. 3 
Conklin, E. S. (1923). The definition of introversion, extroversion and allied concepts. The Journal of Abnormal Psychology and Social Psychology, 17(4), 367.

Davidson, I. J. (2017). The ambivert: A failed attempt at a normal personality. Journal of the History of the Behavioral Sciences, 53(4), 313-331.

De Raad, B., \& Schuwenburg, H. C. (1996). Personality in learning and education: A Review. European Journal of personality, 10, 303-306.

Dunn, R. A., \& Guadagno, R. E. (2012). My avatar and me-Gender and personality predictors of avatar-self discrepancy. Computers in Human Behavior, 28(1), 97106. https://doi.org/10.1016/j.chb.2011.08.015

Erton, I. (2010). Relations between Personality Traits, Language Learning Styles and Success in Foreign Language Achievement. Hacettepe Universitesi Egitim Fakultesi Dergisihacettepe University Journal of Education, 38, 115-126.

Ferwerda, B., Yang, E., Schedl, M., \& Tkalcic, M. (2019). Personality and taxonomy preferences, and the influence of category choice on the user experience for music streaming services. Multimedia Tools and Applications, https://doi.org/10.1007/s11042-019-7336-7

Ferwerda, B., Yang, E., Schedl, M., \& Tkalcic, M. (2015). Personality traits predict music taxonomy preferences. Conference: Proceedings of the 33rd Annual ACM Conference Extended Abstracts on Human Factors in Computing Systems Pages 2241-2246. Doi 10.1145/2702613.2732754

Furnham, A., \& Walker, J. (2001). The influence of personality traits, previous experience of art, and demographic variables on artistic preferences. Personality and Individual Differences, 31(6), 997-1017. https://doi.org/10.1016/S0191-8869(00)00202-6

Ghabanchi, Z., \& Doost, H. A. (2012). The relationship between emotional intelligence and literary appreciation. Journal of International Education Research (JIER), 8(1), 41-48.

Grubor, J., \& Hinić, D. (2010). Extroversion: A factor influencing enjoyment in role play in EFL students?. The New Educational Review, 21(2), 293-305.

Hockenbury, D. H., \& Hockenbury, S.E. (2010). Psychology. New York: Worth Publishers.

Hou, J., Ndausauka, Y., Pan, X., Chen, S., Xu, F., \& Zhang, X. (2018). Weibo or WeChat? Assessing preference for social networking sites and role of personality traits and psychological factors. Frontiers in Psychology, 9, 1-9.

Kroneisen M., \& Heck, D. W. (2020). Interindividual differences in the sensitivity for consequences, moral norms, and preferences for inaction: relating basic personality traits to the CNI model. Pers Soc Psychol Bull, 46(7), 1013-1026 doi:10.1177/0146167219893994

Medina, J. (n.d.). Brain rule rundown. Retrieved from https://brainrules.net/wiring/

Nagahi, M., Jaradat, R., Goerger, S. R., Hamilton, M., Buchanan, R. K., Abutabenjeh, S., \& Ma, J. (2020). The impact of practitioners' personality traits on their level of systemsthinking skills preferences. Engineering Management Journal,

DOI: 10.1080/10429247.2020.1780817

Noprianto, E. (2017). Extrovert versus Introvert Students: What EFL Learning Strategy do They Use. Asian TEFL, 2(2), 119-135.

Peschel, A. O., Grebitus, C., Mohammed, H. A., \& Hughner, R. S. (2019). Personality traits and preferences for production method labeling - A latent class approach. Food Quality and Preference, 74, 163-171. 
Revola, Y. (2016). An analysis of writing achievement among personality type at the third semester students of English department IAIN Bengkulu. Linguists: Journal of Linguistics and Language Teaching, 3(1).

Sadeghi, N., Kasim, Z. M., Tan, B. H., \& Abdullah, F. S. (2012). Learning styles, personality types and reading comprehension performance. English Language Teaching, 5(4), 116-123.

Schäfer, T., \& Mehlhorn, C. (2017). Can personality traits predict musical style preferences? A meta-analysis. Personality and Individual Differences, 116, 265273. https://doi.org/10.1016/j.paid.2017.04.061

SparkNotes Editors. (n.d.) The importance of being earnest, Oscar Wilde. Character List. Retrieved from https://www.sparknotes.com/lit/earnest/characters/

The Editors of Encyclopaedia Britannica (2015) The Importance of Being Earnest play by Wilde. https://www.britannica.com/topic/The-Importance-of-Being-Earnest

Van Kirk, S. (n.d.) The importance of being earnest. Retrieved from https://www.cliffsnotes.com/literature/i/the-importance-of-being-earnest/playsummary? lcitation=true

Yangui, A., Consta-Font, M., \& Gil, J. M. (2016). The effect of personality traits on consumers' preferences for extra virgin olive oil. Food Quality and Preference, 51, 27-38. 